DOI 10.37882/2500-3682.2021.11.04

\title{
АКТИВНЫЕ МЕТОДЫ ОБУЧЕНИЯ ДЛЯ САМОРЕАЛИЗАЦИИ ДУХОВНО-НРАВСТВЕННОГО ПОТЕНЦИАЛА ЛИЧНОСТИ НЕСОВЕРШЕННОЛЕТНИХ
}

\section{ACTIVE TEACHING METHODS FOR SELF- REALIZATION OF THE SPIRITUAL AND MORAL POTENTIAL OF THE PERSONALITY IN MINORS \\ D. Kazantseva \\ S. Tarasov}

Summary: The article examines the features of creating a space for self-realization of the spiritual and moral potential of the personality of minors. It is shown that the use of a set of active teaching methods creates a situation of spiritual development through the development of spiritual and moral patterns of behavior. It has been determined that the saturation of the space with spiritual and moral values and meanings is optimal through the creation of school television in each school.

The introduction of new positive content created by the hands of students into the Internet space of the school contributes to the actualization of the essential in the personality and its consistent realization as a "cocreator" of being.

Keywords: spiritual and moral potential, self-realization, personality, school television, active teaching methods, development, values, meanings.

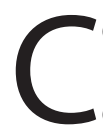
овременное состояние российского общества характеризуется проблемами в сфере духовно-нравственного развития подрастающего поколения. Результатами затянувшегося духовно-нравственного кризиса конца XIX - начала XX вв. стали утрата духовного здоровья личности и системы духовно-нравственных ценностей. Отсутствие чёткой стратегии государства на духовное развитие личности ребенка повлекло разгул, подростковой наркомании, алкоголизма, преступности, а также суицидные попытки, вооружённое насилие на территории образовательных учреждений и др. Негативное влияние СМИ и особенно телевидения и западных интернет-контентов, пропагандирующих жестокость и насилие, усугубляют ситуацию. Бездуховность становится угрозой национальной безопасности России.

Основная причина деформаций всех сфер общественной жизни - уход от глубинных, базовых, сложенных веками в монолит ментальности и проявленных в воспитании духовно-нравственных ценностей и смыслов. Неоднозначные условия влияние новых норм морали иной цивилизации на неокрепшую психику

\author{
Казанцева Дина Борисовна \\ К.nсх.н., Южный федеральный университет, \\ 2. Ростов-на-Дону \\ dinasens@mail.ru \\ Тарасов Сергей Васильевич \\ K.nсх.н., дочент, Пензенский государственный \\ университет, г. Пенза \\ omko08@mail.ru
}

Аннотация: В статье рассматриваются особенности создания пространства самореализации духовно-нравственного потенциала личности несовершеннолетних. Показано, что использование совокупности активных методов обучения создает ситуацию духовного развития, через освоение духовно-нравственных образцов поведения. Определено, что насыщение пространства духовно-нравственными ценностями и смыслами оптимально через создание в каждой школе школьного телевидения. Внедрения в интернет-пространство школы нового позитивного контента созданного руками учащихся способствует актуализации сущностного в личности и последовательной ее реализации как «со-творца» бытия.

Ключевые слова: духовно-нравственный потенциал, самореализация, личность, школьное телевидение, активные методы обучения, развитие, ценности, смыслы.

развивающегося ребенка, стала детерминантой, обуславливающей формирование другой прозападной личности с иным уровнем ценностного развития, слабо связанной с национальным менталитетом.

Расхождение между внутренней системой духовных базисных ценностей и внедряемой извне системы западных ценностей и смыслов, формирующих личность, приводит к трансформации духовно-нравственного потенциала личности, определяющего дальнейшее развитие и судьбу ребенка. Из-за неустойчивости социальной среды, индивидуальная программа, разворачивающаяся в течение жизни личности, включающая устойчивые ментальные особенности поведения, биологические, социальные и духовные детерминанты, стратегию самореализации потенциала создает новые конфигурации развития, сопровождающиеся противоречиями, дихотомиями, кризисными и конфликтными проявлениями.

В этом контексте наибольший интерес представляет механизм самореализации духовно-нравственного потенциала как способ проявления сущностных сил лич- 
ности, для ее гармоничного воспроизводства в социальном пространстве любой, в том числе и кризисной реальности. Запуск механизма осуществляется в процессе духовно-нравственного воспитания в пространстве сбалансированного соединения духовных и материальных культурных идеалов и ценностей. Именно такое воспитание способствует актуализации сущностного в личности и последовательной реализации.

Для этого необходимо создание специально организованного духовного пространства, где личность самоопределяется по отношению к духовно-нравственным целям, ценностям, идеалам, где поддерживается их воспроизводство и реализация в жизни ребенка. Данное осуществляют государственные и федеральные органы власти, образовательные и общественные учреждения. В таком пространстве через обучение и воспитание, посредством активных методов обучения происходит формирование личности ребенка в соответствии с традиционной ментальностью, наполненной духовными смыслами и запускается процесс самореализации духовно-нравственного потенциала, как психозащитного механизма личности от кризисных явлений.

Описание разных сторон духовно-нравственного потенциала, без концептуальной его характеристики мы можем увидеть в исследованиях ученых различных сфер знания - С.Ф. Анисимова, Л.Х. Газгиреевой, Л.В. Камединой, К.Я. Вазиной, Н. Успенского, Н.А. Симоновой, Б.С. Братусь, А.А. Тер-Акопова и др. В работах не ставится цель рассмотрения понятия «духовно-нравственный потенциал», однако, часть его характеристик, представляющих интерес для целостного понимания его сути и процесса самореализации определяется и описывается.

Исследуя потенциал личности, психологи О.С. Анисимов, А.А. Деркач, Л.Х. Газгереева, Н.Б. Трофимова $[1,2,4]$ затрагивают и основы духовно-нравственного потенциала личности, выделяя в качестве закономерностей его возможные рефлексивные составляющие и их сущностные характеристики. Наиболее полное исследование духовно-нравственного потенциала личности осуществлено в работах Д.Б. Казанцевой [6]. Автором описаны закономерности, механизм, условия и особенности его реализации.

Исследования Д.Б. Казанцевой показывают, что духовно-нравственный потенциал личности есть глубинная сущностная духовная часть целостного потенциала личности, его основа, определяющая движущие силы, глубинное «Я» человека и его потенции, разворачивающаяся из глубины потенцией сущностных жизненных духовных сил субъекта, в условиях духовного пространства способствующего самореализации потенциала, достижению акме [5, с. С. 50-55].

С.В Тарасов и Д.А. Трошин [8], исследуя активные ме- тоды обучения, доказывают, что в связи с тем, что стране нужны активные, творческие личности, уже в школьные годы необходимо выбирать оптимальные способы передачи знаний, умений и навыков. Способы должны быть длительные, состоящие из нескольких этапов и включающие в себя множество приемов. Благодаря им инноватизируется и активизируется познавательная деятельность личности, а именно активизируется мышление, вырабатывается самостоятельность в поиске решений поставленных задач; мотивируется обучение, осуществляется анализ смоделированных или реальных ситуаций при поиске решений. Обозначение проблемы стимулирует выработку правил и осуществление логических рассуждений, стремление к использованию системной комбинации методов.

По мнению Е.В. Крутых [7] с помощью активных методов значительно легче активизируются учащиеся, организуется контроль за процессом освоения материала, осуществляется управление процессом обучения, повышается эффективность учебного процесса.

С точки зрения Ю.В. Гущина [3] активные методы обучения формируют способности и умения устанавливать контакты и обмениваться информацией, выдвигать идеи и проекты, принимать нестандартные решения и нести за них ответственность, идти на оправданный риск, предвидя последствия предпринимаемых шагов.

Создание пространства актуализации и самореализации духовно-нравственного потенциала в первую очередь подразумевает насыщенность его духовнонравственными образцами поведения, ценностями и смыслами. Использование всей совокупности активных методов обучения (презентаций, кейс-технологий, проблемных лекций, дидактических игр, баскет-методов и др.) возможно через игромоделирование ситуаций духовного развития, посредством показа духовно-нравственных, положительных образцов поведения, в процессе создания в каждой школе школьного телевидения. Данное становится основой актуализации и самореализации потенциала личности, создавая из каждого ребенка «со-творца» бытия.

Ценность школьного телевидения - в создании пространства моделей положительного социального поведения, соответствующего цивилизационному коду россиян. Проект начинается с интегрирующей личной встречи педагогов, родителей и учеников. Разъясняется необходимость внедрения в интернет-пространство школы нового позитивного контента. В ходе дальнейших встреч, уже в онлайн формате создается группа Вконтакте, которая наполняется методическим материалом и материалом участников группы.

Для мотивации к работе проводится психологическая игра «Перехват управления», где осваиваются ос- 
новы межличностного взаимодействия и управления ситуациями. Определяется на 21 день алгоритм работы по созданию видеоконтента. Организуется школа видеоблогеров, как ядро школьного телевидения, с руководителем, имеющим определенные компетенции и навыки (квалификацию, активную жизненную позицию, навыки ораторского искусства и навыки сценариста, умение перехватывать управление в интернете и проводить переговоры и маркетинговые действия и др.).

Вводится трехэтапная модель развития школьного телевидения. На первом этапе организуется школа видеоблогеров, с обучением два раза в неделю по полтора часа ораторскому искусству, съемкам, монтажу, продвижению контента. Результатом становится обучение несовершеннолетних «говорению», профессиям телеведущего, монтажёра и системного администратора, операторской и режиссерской работе, а также навыкам управления сайтом, аккаунтами в социальных сетях.

На втором этапе осуществляется производство репортажей о всех школьных событиях через игровые шоу, ток-шоу, интервью-шоу. Результатом становится обучение несовершеннолетних профессии интервьюера и проведение школьного или внешкольного конкурсов (соревнования между школами, районами, регионами, субъектами федерации) на лучшее интервью. Для повышения качества коммуникации вводится нравственная культура ток-шоу, дискуссионных шоу, с выбранными спикерами и регламентом: вступительное слово, дебаты, работа с возражениями, вопросами и т.д. В школьной жизни раз в неделю создается позитивное, вдохновляющее красочное событие привлекающее внимание несовершеннолетних и отвлекающее от негативных интернет-групп, переформатирующих сознание детей в прозападные негативные модели поведения.

Третьим этапом, примерно к концу четвертого месяца занятий, создается школьная киностудия и начинается съемка короткометражных фильмов, моделирующих различные ситуации и достойные выходы из них, образцы бесконфликтных способов решения проблем по нормам нравственного поведения. Создается пятиминутный сценарий видео с шутками и запускается на «ютубе», в «инстаграмме». Организуется со сверстниками дискуссия по его обсуждению.

Планирование школьного телевидения идет следующим образом: открытие канала на ютубе, в контакте, инстаграмме и в фейсбуке; определение стратегических тем видеоблога: профориентация, отношения, семья, Родина (история страны и семьи, традиционные ценности); запись стартового трейлера и определение основных плей-листов (тематических направлений); проведение лекций, репортажей, документальных фильмов, интервью, ток-шоу, короткометражных фильмов; запись монологических роликов по темам: съемка, монтаж, звук; запись интервью и освоение основ интервьюирования; организация и проведение ток-шоу, как главного полемического мероприятия; написание сценария игрового короткометражного фильма; организация производства короткометражного фильма: кастинг, съемочный процесс, монтаж, озвучание, распространение в сети; освоение основ маркетинга и привлечение маркетинговых бюджетов под видеоблог как медианоситель, а также переговоры, предпринимательская деятельность, управление коллективами и проектами.

Проводятся индивидуальные занятия с каждым участником. На первом занятии - глубинное интервью: увлечения, мечты о профессии, родители, таланты; представление себя топовым ютубером с 1 млн. подписчиков, темы видео, интервью-шоу, влогов, репортажей; представление себя артистом и сценаристом, режиссером и др.

Последующие занятия - работа над стартовым трейлером: освоение монолога из 4 частей: открытие и тема, проблема, решение, побуждение зрителя к действию. Запись педагогом на доске основных тезисов каждой части, воспроизведение по частям на камеру. Ребенок дублирует поведение. Проект монтируется, изучается производственный цикл. Выстраивается на месяц план роликов по направлениям: родной край, героические страницы истории, литературная страница, отношения мальчиков и девочек, народные промыслы, туризм, запись клипов на каверы и др.

Групповые занятия проводятся с несовершеннолетними, имеющими зарегистрированные каналы и не менее 3 роликов сделанных самостоятельно: сценарий, съемка, монтаж, заливка и продвижение по горизонтальному договору (правило перепощивания роликов участников).

План работы в группах включает: интервьюирование; ток-шоу (дискуссионный клуб) на два, три, четыре собеседника; производство короткометражного игрового фильма и три урока по сценарному делу с домашними заданиями (сценарии на заданную тему и критические видеоблоги по фильмам или сериалам); производство короткометражки: съемка, подготовка материала (постпродакшн), показ в актовом зале школы с обсуждением на ток-шоу.

Таким образом, создание позитивного школьного пространства, наполненного духовными смыслами и историческими и героическими примерами из прошлого России, сохранение преемственности поколений при передаче опыта, осуществляется благодаря организации школьного телевидения. Такое сообщество юных видеоблогеров, позволяет одной группе несовершеннолетних производить коллективный контент для всех детей в школе, передают им приобретенные в ходе обучения 
нравственные нормы, открывать таланты и способности, духовно-нравственный потенциал личности.

Обобщая вышеизложенное, отметим, что освоение определенных знаний, умений и духовно-нравственных ценностных установок, благодаря активным методам обучения создает для развития личности широкий арсенал возможностей, способствует полноценному вхождению в общество, выбору жизненного пути, позволяет занять место в этом сложном, беспрестанно меняющемся современном мире. В связи с тем, что подготовка человека к жизни включает в себя не только определенную сумму знаний, но и адекватное психическим нормам развитие, необходимо актуализировать духовно-нравственный потенциал личности через целенаправленно созданный комплекс развивающих средств, способствующих реализации его на практике. В связи с этим, в социокультурном пространстве самореализации потенциала, всегда должны воспроизводиться духовно-нравственные ценности, нормы и смыслы. Проявленные в разных сферах жизни личности и общества, как образовательно-развивающее средство, они выступают главным фактором процесса самореализации потенциала личности.

\section{ЛИТЕРАТУРА}

1. Анисимов 0.С. Методология и развитие духовности в XXI веке. - Москва, 2008. - 502 с.

2. Газгереева Л.Х. Духовная жизнь современного российского общества в экзистенциально-ценностном измерении: автореф. дис. ... д-ра ф. наук. Ставрополь, 2014. - 60 c.

3. Гущин Ю.В. Интерактивные методы обучения в высшей школе // Психологический журнал, 2012. - №2. - С. 1. - [Электронный ресурс]. - Режим доступа: URL: http://fgosvo.ru/uploadfiles/mnenie\%20\%20expertov/2012n2a1.pdf

4. Деркач А.А. Акмеологические основы развития профессионала. - М.: Изд-во Московского психолого-социального института; Воронеж: НПО «МОДЭК», 2004. - C. 49.

5. Казанцева Д.Б. Самореализация духовно-нравственного потенциала личности в России: монография. - Прага :Vědeckovydavatelskécentrum «SociosféraCZ», 2020. - C. 50-55.

6. Казанцева Д.Б. Самореализация потенциала личности: социально-философский аспект. - Пенза: Изд-во ПГУ, 2011. - 234 с.

7. Крутых Е.В. Активные методы обучения в профессиональной подготовке будущих специалистов // Социальная сфера общества: инновационные тенденции развития. - Краснодар: ИЭиУМиСС, 2011. - 336 с.

8. Тарасов С.В. Трошин Д.А. Активные методы обучения // Успехи современной науки, 2016 - Том 10. - № 12. - С. $178-180$.

(с Казанцева Дина Борисовна (dinasens@mail.ru), Тарасов Сергей Васильевич (omko08@mail.ru).

Журнал «Современная наука: актуальные проблемы теории и практики»

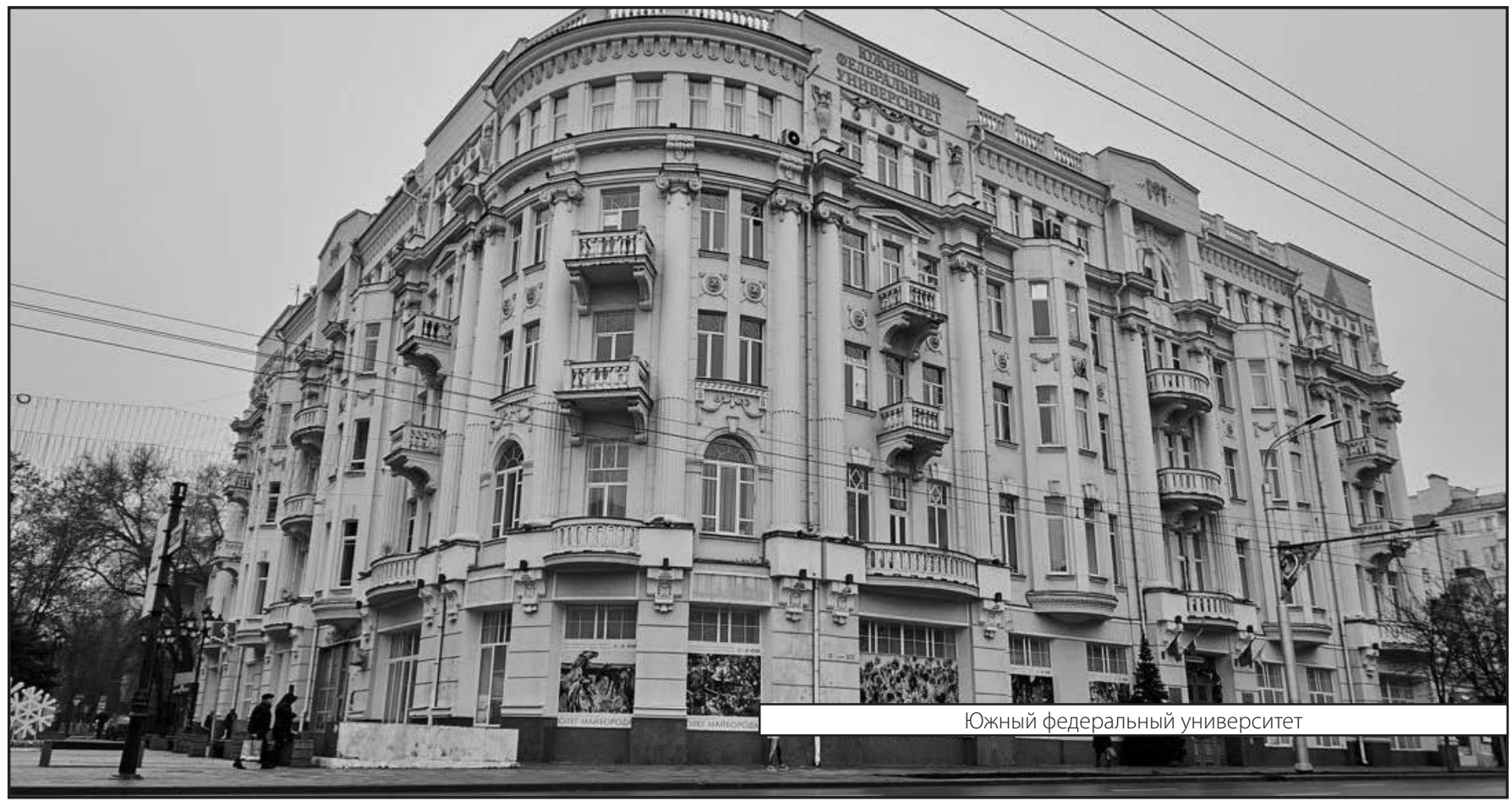

